\title{
PENGARUH PENDIDIKAN KESEHATAN TERHADAP PERAWATAN DIRI PENDERITA DIABETES MELLITUS TIPE 2 DI PUSKESMAS PANDAK I
}

\section{THE EFFECT OF PEER EDUCATION ON SELF CARE IN TYPE 2 DIABETES MELLITUS PATIENS IN PUSKESMAS PANDAK I}

\author{
Ferianto $^{1 *}$, Mateus Sakundarno Adi $^{2}$, Nurullya Rachma ${ }^{3}$ \\ ${ }^{* 1}$ Universitas Jenderal Achmad Yani Yogyakarta, Jl. Ringroad Barat, Gamping Kidul, Ambarketawang, \\ Gamping, Sleman, Yogyakarta 55294, email:ferianto.dilla30@gmail.com, Indonesia \\ ${ }^{2}$ Universitas Diponegoro, JI.Prof.H.Soedarto, S.H.Tembalang, Tembalang, Kota Semarang, Jawa Tengah \\ 50275, email: adisakundarno@yahoo.com, Indonesia \\ ${ }^{3}$ Universitas Diponegoro, JI.Prof.H.Soedarto, S.H.Tembalang, Tembalang, Kota Semarang, Jawa Tengah \\ 50275, email: nurullya.rachma@gmail.com, Indonesia
}

\begin{abstract}
Background: Someone in middle adulthood has begun to experience changes leading to an aging process, so they are vulnerable to degenerative diseases. Diabetes mellitus is a degenerative disease which is still being a health problem in Indonesia. Problems and complications in people with DM can be minimized if the patient has sufficient knowledge and ability to carry out self-care. One effort that can be done is to provide health education about self-care to optimize metabolic control, prevent acute and chronic complications, optimize quality of life and able to carry out self-care behavior independently.

Objective: The study aimed to determine the effect of health education on self-care activities in type 2 diabetes mellitus in Puskesmas Pandak I.

Methods: This was a quasi-experimental study with a one group pretest-posttest study design. The samples used were 26 respondents. Data analysis technique used paired t-test with a significance level of $p<0,05$.

Results: There is a significant enhancement in self-care activities. Statistical analysis using paired t-test found there were significant differences in the value of self-care activities between pre and post-education among type 2 diabetes mellitus diabetes $(p<0,005)$.

Conclusion: Health education can improve self-care activities for people with type 2 diabetes mellitus in Puskesmas Pandak I.
\end{abstract}

Keywords : Health education, self-care, diabetes mellitus

\section{PENDAHULUAN}

Masa usia dewasa menengah ke atas adalah masa di mana seseorang sudah mulai mengalami perubahan fisik mengarah pada proses menua (aging). ${ }^{1} \quad$ Perubahanperubahan fisiologis tersebut dipengaruhi oleh faktor genetik dan gaya hidup yang mangakibatkan seorang beresiko mengalami penyakit kronis. ${ }^{1,2}$

Salah satu penyakit kronis yang masih menjadi masalah utama dalam dunia kesehatan dan Indonesia adalah diabetes mellitus (DM). ${ }^{3,485}$ DM adalah penyakit metabolisme yang timbul pada seseorang karena adanya peningkatan kadar glukosa darah di atas nilai normal. Penyakit ini disebabkan ketidakmampuan tubuh melakukan metabolisme karbohidrat, lemak dan protein. ${ }^{6,7}$ DM tipe 2 (DMT2) merupakan salah satu jenis DM yang paling umum terjadi. Sekitar $90 \%$ penderita diabetes di dunia adalah penderita DM tipe 2 . $^{4,8}$

Secara global, diperkirakan 422 juta orang dewasa menderita diabetes pada tahun 2014, dibandingkan dengan 108 juta pada tahun $1980 .^{9}$ Penderita DMT2 di 
Indonesia diperkirakan juga akan terus melonjak, dari semula 8,4 juta penderita di tahun 2000 menjadi sekitar 21,3 juta di tahun 2030. ${ }^{9}$ Data terbaru di tahun 2015 menunjukkan bahwa jumlah penderita DMT2 di Indonesia telah mencapai 9,1 juta. $^{10}$ Indonesia menduduki peringkat ke tujuh setelah Mexico dengan jumlah penderita DMT2 mencapai 10 juta. $^{4}$

Penyakit DMT2 jika tidak dikelola dengan baik dapat mengakibatkan terjadinya berbagai komplikasi, seperti penyakit serebrovaskular, penyakit jantung koroner, penyakit pembuluh darah tungkai, gangguan pada mata, ginjal dan syaraf. Penyandang diabetes mempunyai risiko 2 kali lebih besar untuk mengalami penyakit jantung koroner dan penyakit pembuluh darah otak, 5 kali lebih mudah menderita ulkus/gangren, 7 kali lebih mudah mengidap gagal ginjal terminal, dan 25 kali lebih mudah mengalami kebutaan akibat kerusakan retina daripada pasien non diabetes. $^{4}$

Masalah dan komplikasi pada penderita DMT2 dapat diminimalkan apabila penderita mempunyai pengetahuan dan kemampuan yang cukup dalam melakukan perawatan diri. ${ }^{11,12}$ Perawatan diri atau self care oleh Orem didefinisikan sebagai aktifitas yang dilakukan seseorang di mana individu memulai dan melakukan suatu tindakan berdasarkan keinginannya dengan tujuan untuk mempertahankan hidup, kesehatan dan kesejahteraan. $^{13}$ Self care diabetes mellitus terdiri dari 4 pilar penatalaksanaan yaitu pemberian edukasi, terapi nutrisi, latihan jasmani dan penatalaksanaan farmakologis dan monitoring kadar glukosa darah. ${ }^{10,14}$

$$
\text { Hasil studi pendahuluan di }
$$
Puskesmas Pandak I yang dilakukan pada 10 penderita DMT2 menggunakan metode wawancara menunjukkan bahwa $80 \%$ penderita sering mengeluh cepat merasa lelah, sering merasa lapar dan haus dan kaki terasa lemas dan kesemutan. Penanganan yang dilakukan penderita selama ini adalah dengan minum obat yang diberikan dari puskesmas, mengurangi makan nasi, ketika muncul rasa lapar berlebih biasa penderita memakan nasi basi atau ubi karena takut gula darah meningkat. Perawatan diri yang dilakukan penderita masih tergolong kurang, di mana $80 \%$ penderita tidak menjalani diit $\mathrm{dm}$ sesuai anjuran, $70 \%$ penderita tidak melakukan olah raga secara teratur hanya melakukan olah raga senam sebulan sekali pada saat ikut kegiatan prolanis, 90\% tidak pernah melakukan perawatan kaki, $80 \%$ penderita melakukan kontrol dan $20 \%$ penderita DMT2 hanya melakukan kontrol gula darah saat muncul gejala. Wawancara kepada Pemegang Program Prolanis menunjukkan bahwa kegiatan prolanis dilakukan sebulan sekali. Kegiatan dalam prolanis berupa pemeriksaan tekanan darah, gula darah, pemberian obat dan senam serta penyuluhan kesehatan yang bersifat accidental. Kegiatan lain di luar hal itu belum ada. 
Pendidikan kesehatan telah diakui sebagai komponen penting dalam pengelolaan diabetes dan semakin diakui sebagai bagian integral dalam manajemen penyakit kronis. Tujuan pendidikan kesehatan pada penderita DM adalah untuk mengoptimalkan control metabolic, mencegah komplikasi akut dan kronis, meningkatkan kualitas kehidupan sehari-hari dan menghasilkan perubahan pengetahuan, sikap dan perilaku untuk mempertahankan atau mengoptimalkan kesehatan. ${ }^{15,16}$ Penelian yang dilakukan oleh Taha menunjukkan bahwa pendidikan kesehatan secara signifikan mampu meningkatkan pengetahuan, self-efficacy dan selfmanagement penderita DM tipe 2.

Berdasarkan uraian di atas peneliti tertarik untuk mengetahui pengaruh pendidikan kesehatan terhadap perawatan diri penderita DM tipe 2 di Wilayah Kerja Puskesmas Pandak I.

\section{BAHAN DAN CARA PENELTIAN}

Penelitian ini merupakan penelitian quasi eksperiment dengan rancangan one group pre-posttest design. Penelitian ini dilakukan di wilayah Kerja Puskesmas Pandak I pada bulan September 2018.

Populasi pada penelitian ini adalah seluruh pasien DMT2 yang masuk dalam prolanis di Puskesmas Pandak 1 yang memenuhi kriteria insklusi; usia 30-60 tahun, lama menderita 1-10 tahun, pendidikan responden SD, SMP dan SMA, responden masuk dalam prolanis, dan kriteria esklusi: responden dengan komplikasi penyakit jantung dan gagal ginjal, reponden tidak bisa melihat. Sampel dalam penetilian ini berjumlah 26 orang dengan cara total sampling.

Instrument yang digunakan adalah kuesioner The Summary of Diabetes Self Care Activities (SDSCA) yang dikembangkan oleh Tobert et al, dan sudah dimodifikasi oleh Intannia. ${ }^{17}$

Seluruh partisipan yang masuk kriteria dianjurkan mengisi lembar inform consent, kemudian dilakukan pre-test, dilanjutkan dengan pemberikan pendidikan kesehatan dengan metode ceramah dan pemutaran video oleh peneliti sendiri. Peneliti melakukan pos-test 3 minggu pasca intervensi. Analisa data yang digunakan adalah dengan uji paired $t$ test.

\section{HASIL DAN PEMBAHASAN}

Tabel 1 menunjukkan bahwa 80,8\% dari responden adalah perempuan. Sebagian besar responden memiliki tingkat Pendidikan SMP $(42,3 \%)$, tidak berkerja $(53,8)$, penghasilan $\leq \mathrm{Rp}$ 1.540.000, lama menderita 4-6 tahun (50\%), dan usia dalam rentang 4560 tahun $(88,5 \%)$.

Tabel 2 menunjukkan bahwa uji normalitas pada nilai perawatan diri dan indikatornya berdistribusi normal ( $p$-value $>0,05)$, sehingga layak dilakukan uji paired $T$ test. 
Tabel 1 Distribusi Frekuensi Karakteristik Responden

\begin{tabular}{|c|c|c|c|c|}
\hline \multicolumn{2}{|l|}{$\begin{array}{l}\text { Karakteristik } \\
\text { responden }\end{array}$} & Jumlah & \multicolumn{2}{|c|}{ Persentase } \\
\hline \multicolumn{5}{|l|}{ Umur } \\
\hline \multirow{2}{*}{\multicolumn{2}{|c|}{$\begin{array}{l}<45 \text { tahun } \\
45-60 \text { tahun }\end{array}$}} & 3 & \multirow{2}{*}{\multicolumn{2}{|c|}{11,5}} \\
\hline & & 23 & & \\
\hline \multicolumn{5}{|c|}{ Jenis Kelamin } \\
\hline \multicolumn{2}{|c|}{ Laki-laki } & 5 & \multicolumn{2}{|c|}{19,2} \\
\hline Perempua & & 21 & \multicolumn{2}{|c|}{80,8} \\
\hline \multicolumn{5}{|c|}{ Pendidikan } \\
\hline \multicolumn{2}{|l|}{ SD } & 8 & \multicolumn{2}{|c|}{30,8} \\
\hline \multicolumn{2}{|l|}{ SMP } & 11 & \multicolumn{2}{|c|}{42.3} \\
\hline \multirow{2}{*}{\multicolumn{5}{|c|}{ Pekerjaan }} \\
\hline & & & & \\
\hline \multicolumn{2}{|c|}{ Tidak berkerja } & 14 & \multicolumn{2}{|c|}{53,8} \\
\hline Buruh & & 5 & \multicolumn{2}{|c|}{19,2} \\
\hline Petani & & 3 & & \\
\hline Wiraswata & dagang & 3 & & \\
\hline PNS & & 1 & & \\
\hline Penghasilan & & & & \\
\hline$\leq \operatorname{Rp} 1.54$ & 000 & 21 & & \\
\hline$>\operatorname{Rp} 1.54$ & 000 & 5 & & \\
\hline Lama mende & ta (th) & & & \\
\hline $1-3$ & & 3 & & \\
\hline $4-6$ & & 13 & & \\
\hline $7-10$ & & 10 & & \\
\hline Total & & 26 & & \\
\hline Sumber: Dat & primer 2 & & & \\
\hline $\begin{array}{r}\text { Tabel } 2 \\
\text { da }\end{array}$ & $\begin{array}{l}\text { uji I } \\
\text { st-t }\end{array}$ & $\begin{array}{l}\text { rmalit } \\
\text { perav }\end{array}$ & $\begin{array}{l}\text { as nilai } \\
\text { vatan di }\end{array}$ & test \\
\hline Variahel & Kelas & & Shapiro & Wilk \\
\hline & & df & Statistic & Sig. \\
\hline Self care & Pre tes & 26 & 0,99 & 0,96 \\
\hline & Pos tes & 26 & 0,98 & 0,84 \\
\hline Sub variabel & & & & \\
\hline Kontrol Diit & Pre tes & 26 & 0,95 & 0,29 \\
\hline & Pos tes & 26 & 0,97 & 0,50 \\
\hline Aktifitas fisik & Pre tes & 26 & 0,93 & 0,08 \\
\hline & Pos tes & 26 & 0,96 & 0,37 \\
\hline $\begin{array}{l}\text { Perawatan } \\
\text { kaki }\end{array}$ & Pre tes & 26 & 0,96 & 0,42 \\
\hline & Pos tes & 26 & 0,93 & 0,06 \\
\hline
\end{tabular}

Sumber: Data primer 2018

Hasil analisis menunjukkan bahwa terdapat perbedaan rata-rata nilai self-care sebesar 1,13 dengan standar deviasi 0,72. Hal serupa juga terjadi perbedaan rata-rata pada semua indikator self-care, dimana nilai pos-test lebih besar daripada pre-test.

\section{Tabel 3 Perawatan Diri Penderita DMT2 Sebelum dan Sesudah Diberikan Pendidikan Kesehatan}

\begin{tabular}{|c|c|c|c|c|c|}
\hline \multirow[b]{2}{*}{ Variable } & \multicolumn{2}{|c|}{ Pengukuran } & \multirow[b]{2}{*}{$\begin{array}{l}\text { Selisih } \\
\text { mean }\end{array}$} & \multirow[b]{2}{*}{$\mathrm{t}$} & \multirow[b]{2}{*}{ Sig } \\
\hline & $\begin{array}{l}\text { Pre- } \\
\text { test } \\
\text { (SD) }\end{array}$ & $\begin{array}{c}\text { Post- } \\
\text { test } \\
\text { (SD) }\end{array}$ & & & \\
\hline Perawatan Diri & $\begin{array}{c}3,35 \\
(0,83)\end{array}$ & $\begin{array}{c}4,48 \\
(1,14)\end{array}$ & $-1,13$ & $-7,99$ & 0,00 \\
\hline \multicolumn{6}{|l|}{ Sub Variabel } \\
\hline Kontrol Diet & $\begin{array}{c}3,91 \\
(1,08)\end{array}$ & $\begin{array}{c}4,92 \\
(1,32)\end{array}$ & $-1,01$ & $-5,52$ & 0,00 \\
\hline Aktifitas Fisik & $\begin{array}{c}3,02 \\
(0,81)\end{array}$ & $\begin{array}{c}4,17 \\
(1,08)\end{array}$ & $-1,15$ & $-6,02$ & 0,00 \\
\hline $\begin{array}{l}\text { Perawatan } \\
\text { Kaki }\end{array}$ & $\begin{array}{c}2,85 \\
(1,29)\end{array}$ & $\begin{array}{c}4,12 \\
(2,02)\end{array}$ & $-1,27$ & $-4,53$ & 0,00 \\
\hline
\end{tabular}

Indikator perawatan kaki merupakan indikator yang paling besar peningkatannya (meningkat sebesar 1,27). Hal ini terjadi karena tindakan yang dilakukan cukup mudah dibandingkan tindakan perawatan diri yang lain. Tindakan tersebut meliputi mencuci kaki setiap hari, mengeringkan kaki dan sela-sela jari setelah dicuci, memeriksa kondisi kaki dan melakukan pengecekan pada sandal atau sepatu sebelum dipakai. ${ }^{12,17}$ Temuan ini dimungkinkan juga dipengaruhi oleh latar belakang agama, dimana mayoritas responsden dalam penelitian ini beragama Islam. Sebagai muslim, mereka harus mencuci kaki mereka setidaknya lima kali sehari, sehingga mereka sudah terbiasa dengan perawatan kaki dasar dan kegiatan kebersihan sebelum beribadah shalat. ${ }^{18}$

Indikator kontrol diet memiliki peningkatan nilai mean yang paling kecil $(1,01)$ dibandingkan indikator lainnya. Hal ini 
berkaitan dengan budaya dan kebiasaan responden dimana porsi makan responden lebih banyak karbohidrat dengan sedikit sayur dan lauk dan suka minum teh manis. Tinggi rendah-nya status kesehatan, terutama status gizi dan pengaturan makanan di masyarakat bukanlah hanya dari upaya perbaikan ekonomi atau faktor-faktor medis saja tetapi juga dipengaruhi berbagai faktor sosial budaya. ${ }^{19}$

Hasil analisis data pada self-care secara keseluruhan dan semua indikatornya menggunakan uji paired t test memperoleh hasil nilai $p$-value $<0,05$. Maka, dapat disimpulkan bahwa pendidikan kesehatan dapat meningkatkan perawatan diri penderita DM tipe 2.

Hasil penelitian ini ditunjang peneltian Pal $\mathrm{R}$ et all yang mengemukakan bahwa pendidikan kesehatan secara significan dapat meningkatkan pengetahuan tentang DM dan sikap dalam memotifasi anggota keluarga dalam penatalksaan $\mathrm{DM}^{20}$ Penelitian ini diperkuat oleh teori Suliha yang menyatakan bahwa pendidikan kesehatan merupakan usaha/kegiatan untuk membantu individu, kelompok, dan masyarakat dalam meningkatkan kemampuan baik pengetahuan, sikap, maupun keterampilan untuk mencapai hidup sehat secara optimal. ${ }^{21}$

Hasil penelitian ini juga selaras dengan penelitian Awouda yang menjelaskan bahwa ada pengaruh pendidikan kesehatan terhadap pengetahuan penderita DM ( $p$ - value<0,05). Pendidikan kesehatan meningkatkan pengetahuan penderita terkait tanda dan gejala penyakit, penyebab, dan tanda-tanda peringatan masalah kaki, perawatan kaki, dan pentingnya latihan. ${ }^{22}$ Peningkatan pengetahuan penderita DM memiliki kaitan erat dengan perilaku self-care yang akan diambilnya. Dengan pengetahuan tersebut, penderita akan mempunyai alasan dan landasan untuk menentukan perilaku perawatan dirinya dan dapat mengembangkannya untuk mengatasi kebutuhan kelangsungan hidup, sehingga akan mempengaruhi seseorang dalam melaksanakan perawatan dirinya. ${ }^{23,24}$ Terbentuk suatu perilaku baru khususnya perilaku self-care terutama pada orang dewasa dimulai pada domain kognitif dalam arti subyek tahu terlebih dahulu terhadap stimulus yang berupa materi atau obyek diluarnya, sehingga menimbulkan pengetahuan baru dan sikap positif yang dalam waktu tertentu akan diadopsi menjadi perilaku baru. $^{24,25}$

\section{KESIMPULAN}

Pendidikan kesehatan dengan
metode ceramah dan pemutaran video
berpengaruh terhadap peningkatan
perawatan diri penderita DM tipe 2 di Wilayah
Kerja Puskesmas Pandak I.
Berdasarkan hasil di atas diharapkan
pihak pukesmas melakukan pendidikan
kesehatan secara berkesinambungan
dengan berbagai metode dan media.




\section{TERIMA KASIH}

1. Kuswanto Hardjo, dr., M.kes Dekan Fakultas Kesehatan Universitas Jenderal Ahcmad Yani Yogyakarta

2. Dr. dr. Dwi Pudjonarko Dekan Fakultas Kesehatan Universitas Diponegeoro Semarang

\section{KEPUSTAKAAN}

1. Santrock JW. Life-Span Development. Twelfh. New York: McGraw-Hill, 2009.

2. Hutchison E. Dimensions of Human Behavior: The Changing Life Course. California: SAGE Publications, Inc, 2011.

3. Kementrian Kesehatan RI. Penyakit Tidak Menular. Jakarta. Buletin Jendela Data dan Informasi Kesehatan, 2012.

4. International Diabetes Federation. Diabetes Atlas. 7th ed. 2015.

5. Wild S, Roglic G \& Green A et al. Global Prevalence of Diabetes. Diabetes Care 2004; 27: 1047.

6. Badan Penelitian dan Pengembangan Kesehatan. Riset Kesehatan Dasar (RISKESDAS) 2013. Lap Nas 2013 2013; 1-384.

7. Black, Joyce M. \& Hawks JH. Medical Surgical Nursing. Clinical Management for Positif Outcomes. 7th ed. Michigan: Elsevier Saunders, 2009.

8. American Diabetes Association. Standards of Medical Care in Diabetes - 2016. USA, 2016.

9. World Health Organization, Tareque MI, Koshio A, et al. Global Report on Diabetes. Curr Med Res Opin 2014; 56: 1051-1062.

10. Rudijanto A, Yuwono A, Shahab A, Manaf A, Pramono B, Lindarto $D$ et al. Konsensus Pengelolaan dan Pencegahan Diabetes Melitus Tipe 2 di Indonesia 2015. 1st ed. Jakarta: PB PERKENI, 2015.

11. Wattana C, Wiehit S, Linchong $P$, et al. Effects of a diabetes self-management program on glycemic control, coronary heart disease risk, and quality of life among Thai patients with type 2 diabetes. Nurs Heal Sci 2007; 9: 135141.

12. Kusniawati. Analisis Faktor Yang Berkontribusi Terhadap Self Care Diabetes Pada Klien Diabetes Melitus Tipe 2 Di Rumah Sakit Umum Tangerang. Universitas Indonesia, 2011.

13. Weiler DM, Crist JD. Diabetes SelfManagement in the Migrant Latino Population. Hisp Heal Care Int 2007; 5: 27-33.

14. Waspadji S. Penatalaksanaan DM Terpadu. Jakarta: Fakultas Kedokteran Universitas Indonesia, 2009.

15. Atak N, Gurkan T, Science E, et al. The effect of education on knowledge, self management behaviours and self efficacy of patients with type 2 diabetes. Aust J Adv Nurs 2013; 26: 66-74.

16. Falvo D. Effective patient education: a guide to increased compliance. 2nd ed. USA: Jones and Barlett Publishers, 1994.

17. Intania D. Pengaruh Program Edukasi KeluargaTerhadap Kontrol Kadar Gula Darah Penderita DM Rawat Jalan di RSUD Ulin Banjarmasin. 2011; 60-74.

18. Kurniwawan $T$, Sae-Sia W, Maneewat $K R$, et al. The Effect of A SelfManagement Support Program on The Achievement of Goals in Diabetic Foot Care Behaviors in Indonesian Diabetic Patients. Nurse Media J Nurs 2011; 1 : 195-210.

19. Kasnodihardjo, Angkasawati TJ. NilaiNilai Budaya Yang Mendasari Pemerataan Makanan. Bul Penelit Kesehat 2014; 42: 59-70.

20. Pal, Ranabir, Pal S, Ankur Barua and MKG. Health education intervention on diabetes in Sikkim. Indian J Endocrinol Metab 2010; 14: 3-7.

21. Suliha, U., Herawani, Sumiati R, Y. Pendidikan Kesehatan Dalam Keperawatan. EGC. Jakarta, 2002.

22. MakkiAwouda FO, Elmukashfi TA, Hag Al-Tom SA. Effects of Health Education of Diabetic Patient's 
Knowledge at Diabetic Health Centers, Khartoum State, Sudan: 2007-2010. Glob J Health Sci 2014; 6: 221-226.

23. Diani N. Pengetahuan dan praktik perawatan kaki pada klien diabetes melitus tipe 2 di kalimantan selatan tesis. 2013; 134.

24. Notoatmodjo S. IImu Perilaku Kesehatan. Jakarta: Rineka Cipta,
2010.

25. Fitriani D. Pengaruh edukasi sebaya terhadap perilaku hidup bersih dan sehat (PHBS) pada agregat anak usia sekolah yang beresiko kecacingan di Desa Baru Kecamatan Manggar Kabupaten Belitung Timur. Universitas Indonesia, 2011. 